\title{
Analysis of Critical Thinking Dispositions Regarding Teachers' Schematic Representation of Resource Systems
}

\author{
Menekse Seden Tapan-Broutin $^{1} \&$ Sirin Ilkorucu ${ }^{1}$ \\ ${ }^{1}$ Faculty of Education, Bursa Uludag University, Bursa, Turkey \\ Correspondence: Menekse Seden Tapan-Broutin, Mathematics Education Department, Faculty of Education, \\ Bursa Uludag University, Gorukle, Bursa, Turkey. E-mail: tapan@uludag.edu.tr
}

Received: April 30, 2021

Accepted: June 17, $2021 \quad$ Online Published: June 24, 2021

doi:10.5539/jel.v10n4p129

URL: https://doi.org/10.5539/jel.v10n4p129

\begin{abstract}
Studies in recent years have focused heavily on teacher practice and analyzing textbooks and their contents. The schematic representation of the resource system can be used to analyze the composition of teachers' creation of the document. It is also thought to be an effective process for revealing their critical thinking dispositions. This study aims to determine whether teacher candidates reflect critical thinking dispositions to their schematic representation of the resource systems. The case study design, one of the qualitative research methods, was used in this study. The research was conducted with 26 third-year students from the mathematics department in the faculty of education. In this study, it has been revealed that teacher candidates reflect the resources and critical thinking dispositions they preferred in their schematic representations of resource systems. The five themes "truth-seeking", "open-minded", "analytic", "systematic" and "self-confidence" were found in the schematic presentation of mathematics teacher candidates' critical thinking dispositions. Also, it was noted that mathematics teacher candidates were more oriented towards digital resources, especially internet resources. As a result, this study showed the resources that affect the professional development of teacher candidates and the relationships between these resources and their critical thinking orientations by the schematic representation of the resource system.
\end{abstract}

Keywords: documentational approach to didactics, critical thinking dispositions, schematic representation of resource system, teacher education

\section{Introduction}

In teaching, teachers are one of the most important elements for preparing the didactical environment and its proper functioning to construct knowledge. Teachers integrate, organize and assimilate the content they acquire from various resources (educational resources, books, software, websites, interaction with their colleagues and/or students, etc.) both in the creation of learning environments and in the realization of these learning environments in the classrooms (Gueudet \& Trouche, 2010). Studies have recently focused heavily on teacher practice and analyzing textbooks and their contents (Adihou, Gibel, \& Blanquart-Henry, 2019; Pepin, Gueudet, \& Trouche, 2013). A teacher who sets up a teaching sequence does not use only textbooks. He/she also takes advantage of other paper and/or computer resources, his/her representations and experiences, his/her social character, his way of managing class or time etc. Gueudet and Trouche (2009) give broad meaning to the term of resource: "A textbook, official programs, a website can be resources for the teacher. But a pupil's copy, advice given by a colleague ... are also resources, in a sense attributed to this term by Adler (2000): which resource the activity and professional development of teachers. Conscious of this view, the documentational approach to didactics has taken into account a wide range of "resources" that can serve as a resource for teachers' activities (textbooks, digital resources, e-mails, exchanges with colleagues, students' sheets etc.) and supporting his/her engagement in teaching. It is in this perspective that it seems important to refer to the documentational approach. The documentational approach to didactics (DAD) is considered an effective theoretical framework for analyzing the organization among the different resources used by teachers (Gueudet \& Trouche, 2009). The documentational approach provides the tools to form the basis of the research to understand how a teacher structures, edits, modifies and adapts his/her lesson. The DAD proposes a paradigm shift by analyzing teachers' work from the perspective of "resources" for teaching (Trouche, Gueudet, \& Pepin, 2018). 


\subsection{Documentational Approach to Didactics}

The documentational approach focuses on analyzing the fundamental activity of the teacher, namely the documentational work. Documentational work includes all activities in which the teacher interacts with resources (research, association, design, sharing and revision). During these interactions, the teacher develops a document that integrates both the recombined resources and the schemes of utilization, reinforced with experience and professional knowledge. In terms of processes, during the interaction with a particular resource, or sets of resources, teachers develop their particular utilization schemes for these resources. These documents are likely to be different for different teachers; they may use the same resource, depending on, for example, their provisions and knowledge (Trouche, Gueudet, \& Pepin, 2018). According to Gueudet and Trouche (2011), a document consists of two components, namely "recombined resources" and "schemes of utilization". Thus, a document can be represented as "Document $=$ Resources + Schemes of utilization ".

Throughout the documentational work, a teacher interacts with a set of resources that he/she uses. Different contexts for the same class of situations will give birth to a document during a documentational genesis. The constitution processes of document resources, called documentational genesis, combine two nested processes: the instrumentation processes (the resources equip the teacher and influence his/her activity, these processes mark the evolutions of the practices and professional knowledge induced by the work on resources) and instrumentalization processes (the teacher appropriates, adjusts, adapts, enriches, and reorganizes resources according to his/her teaching objective, so it is the processes of transformation of a resource during its appropriation). This process works in both ways: the affordances of the resource(s) influence teachers' practice (that is the instrumentation process), as the teachers' dispositions and knowledge guide the choices of resources and transformation processes between different resources (i.e., the instrumentalization process) (cf. Figure 1) (Trouche, Gueudet, \& Pepin, 2018). In other words, in the context of documentational genesis, two processes coexist the process of instrumentation and the process of instrumentalization. The instrumentalization process concerns the appropriation of resources by the teacher. It is the teacher's knowledge that will determine how the resources will be modified and combined. The instrumentation process concerns the influence of resources by their characteristics, professional knowledge, ways of doing things, time, etc. Thus, the distinction between dual processes of instrumentation and instrumentalization makes it possible to identify the respective contributions of the teacher and resources to the document that emerges from the genesis (Hammoud, 2012).

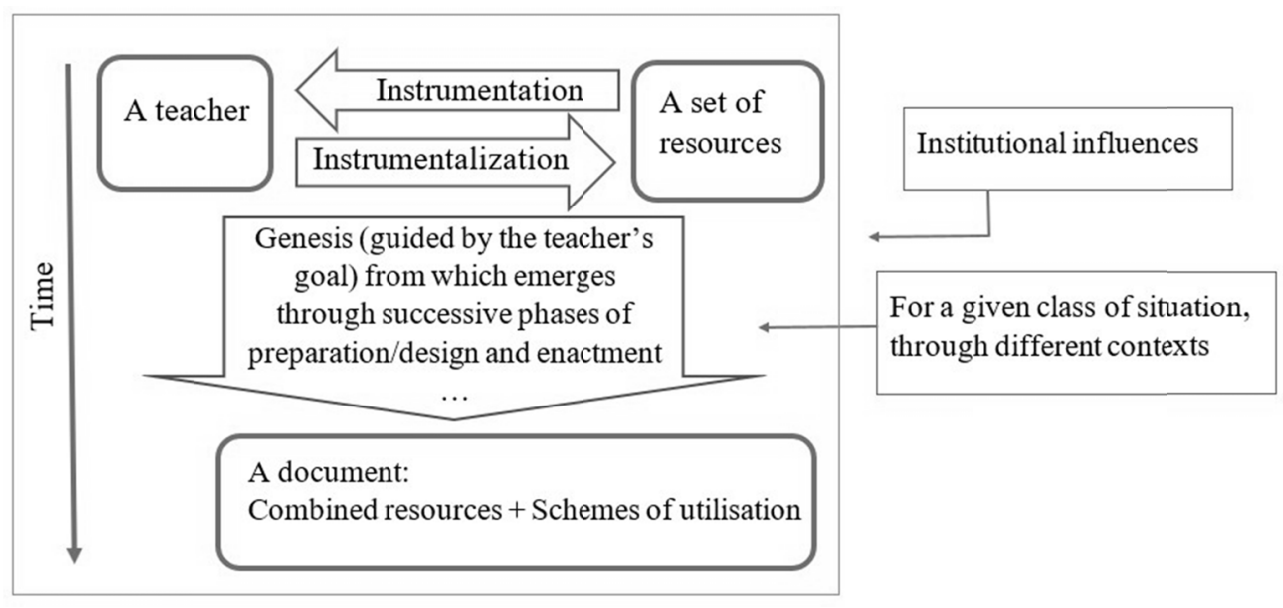

Figure 1. Representation of a documentational genesis (Trouche, Gueudet, \& Pepin, 2018)

Moreover, Gueudet and Trouche (2010) consider that the documents of a teacher do not exist isolated; they thus introduce the notion of documentational system: it is a set of articulated documents. In his/her professional activity, the teacher interacts with a set of resources that Gueudet and Trouche (2010) call a resource system. The documentational system, as these authors underline, is then composed of the system of resources and professional knowledge that drive the development and use of these resources. Thus, the teacher's work on resources induces a reorganization of his/her system of resources (Hammoud, 2012). 


\subsection{Critical Thinking Dispositions and Schematic Representation of Resource System}

The professional development of teachers is directly linked to the documents they construct (Gueudet \& Trouche, 2009). Systems of resources are one of the important elements of the system created by these documents. The system of resources refers to the system of all the resources used by the teacher, regardless of the utilization schemes. Teachers use the resources prepared for their classes in several ways and structure these resources. One method to examine the teachers' resources system is to analyze their schematic representation of the resource system (Gueudet \& Trouche, 2008). The schematic representation of the resource system (SRRS) is presented by Trouche, Gueudet and Pepin (2018) as a useful tool. The SRRS is a diagram that teachers are expected to draw; to analyze their resources with their formatting and interpretations; the resources they use more, what resources they use less, how much importance they attach to different resources, their steps of lesson preparation and their documental genesis processes. SRRS has been the subject of numerous studies and has been used in many studies. Their knowledge, skills, and experiences directly influence teachers' resource systems (Hammoud, 2012; Pepin, Geudet, Yerushalmy, Trouche, \& Chazan, 2016; Rocha, 2018). Caine and Caine (1991) implied that students with critical thinking might be more equipped to acquire and use natural knowledge in various subjects when encountering a problem so that critical thinking can be integrated into every subject in their curriculum. Facione, Facione and Sanchez (1994) state that knowledgeable educators in the teaching and learning critical thinking dispositions can develop educational programs to use the critical thinking disposition and facilitate learning combined with critical thinking activities. It is thought that the schematic representation of the resource system can be used to examine the components of the document creation process of teachers and be an effective tool for revealing their critical thinking dispositions. It increases the importance of the study that there is no study in the literature examining teacher activities by using the documentational approach and critical thinking dispositions.

In addition, the fact that the teacher candidates in the study did not start the traineeship in the schools differentiates this study from other studies on the documentational approach in the literature. Their resource systems will likely be influenced by universal/collective rather than school/classroom factors. This research will hence contribute to studies on the documentational approach. In the context of critical thinking dispositions, this research also fills a gap in the literature. It is the only study analyzing teacher candidates' resource systems in the context of critical thinking.

\subsection{Reseach Questions}

This study aims to determine whether teacher candidates reflect critical thinking dispositions on their schematic representation of the resource systems. In this context, it is aimed to determine the critical thinking disposition from the resource systems that the mathematics teacher candidates present schematically. In this aim, the following questions were investigated.

1) How do teacher candidates structure their schematic representations of resource systems?

2) How do teacher candidates reflect the critical thinking dispositions dimensions in their schematic representations of resource systems?

\section{Method}

\subsection{Research Model}

One of the qualitative research designs was used in the case study research design. In the case study, the goal is to evaluate the context in question from different perspectives with a detailed and holistic approach (Patton, 2015; Yin, 2009). The study was conceived as a single holistic case study defined by Yin (2009, p. 46). In this conception, the situation studied was evaluated as representing the teacher candidates' critical thinking dispositions in their resource systems. Mathematics teachers who think critically about the resource systems they are exposed to were analyzed as a unit of analysis. The results of a case study are not generalized to the universe. They are unique and have similar background information and suggestions (Saban \& Ersoy, 2016).

\subsection{Participants}

AThe research was conducted with 26 third-year teacher candidates from the mathematics education department of Uludag University during the spring semester of the 2018-2019 academic year. The participants were selected using an easily accessible sampling method based on the inclusion of volunteers from 58 third-year teacher candidates. Easily accessible sampling is a method that adds practicality and speed to research (Patton, 2015, p. 242). 


\subsection{Data Collection Tools and Procedure}

At first, the researcher organized a one-hour presentation of research objectives and the schematic representation of resource systems. At the presentation, information was provided on the documentational approach and resource systems in the literature. Still, no example of a schematic representation was presented so as not to affect participants. At the end of the presentation, participants were invited to draw a schematic representation of their resource systems. There was no time limit for the participants.

After analyzing the data obtained from participants' SRRS with the critical thinking dispositions, semi-structured clinical interviews were conducted with participants to gain in-depth information on issues related to critical thinking dispositions; what factors they were assigned to, what factors they paid attention to when selecting their resources, whether they had a holistic structure etc. Each interview lasted an average of 15 minutes. The interviews were recorded and transcribed.

\subsection{Data Analysis}

The SRRS provided by the mathematics teacher candidates, the study's analysis unit and the data obtained from clinical interviews were analyzed using content analysis. In the SRRS analysis and the analysis of clinical interviews, the themes are intended to analyze the critical thinking defined by Faccione, Faccione and Sanchez (1994) in terms of the search for truth, openness, analysis, systematization, self-confidence, curiosity, and maturity. First, schematic representations of participants' resource systems were classified and analyzed according to sub-dimensions of critical thinking dispositions. Then, data obtained from semi-structured clinical interviews were analyzed using content analysis with schematic representations of resource systems. Finally, the data were evaluated holistically and independently coded by the researchers, and the relationships between these codes and themes were determined. After that, the codes and themes were arranged, and the results were interpreted.

\subsection{Validity, Reliability and Ethical Considerations}

Different strategies were used to address the validity and reliability of the study. During the presentation given by the first researcher, he/she spent a lot of time and shared it with the participants. It confirms the sincerity of the participants in the data collection process while providing reliable and detailed data. In addition, participants were informed of the purpose and progress of the study, on the fact that the interview records would not be shared with anyone and would not be used except for research. Reliability was increased by allowing a non-participant researcher to evaluate results. The study results were validated by presenting them in detail directly from the participants' responses and presenting the common results of the data obtained from different data sources. The anonymity of the teacher candidates has been respected, so they were designated by codes like T1, T2, and T3. They have also been informed that their names won't be revealed under any conditions. Following the nature of qualitative research requirements, the monitoring of trainee teachers took place over two years. The research respects the criteria relating to ethics.

\section{Results}

The findings related to the resources used by the teacher candidates in their schematic representation of resources systems analyzed concerning the clinical interviews are presented in this section based on the categories revealed in the content analysis. Then, findings related to the schematic representations relations with critical thinking dispositions components are also presented.

According to the findings, all the 26 teacher candidates included digital resources in their resource systems and clinical interviews. Among digital resources, the Internet is the most striking source in the resource systems of teacher candidates. Some teacher candidates placed Internet-related resources in their schematic representations, such as other sources. In contrast, others placed Internet meta-resources at the center or top level of their resource systems. T7's statement illustrates the importance that teacher candidates attach to the Internet as a resource: "There are no more libraries or books, there is access to everything on the Internet ..."

Concerning the resources of the Internet meta-resource, it should be noted that almost all participants stated Youtube in their resource system. All the teacher candidates who used YouTube as a resource explained that they used this resource to watch sample videos on how to teach a subject. The schematic representation of the teacher candidate, the T5 resource system, is presented as an example in Figure 2. This schematic representation is constructed with a pyramid shape, and the teacher candidate T5 expressed in the interviews, "if there are not some stages below, there is not lecture... I mean, I have to prepare my course with some activities, I need to learn how to do ...". 


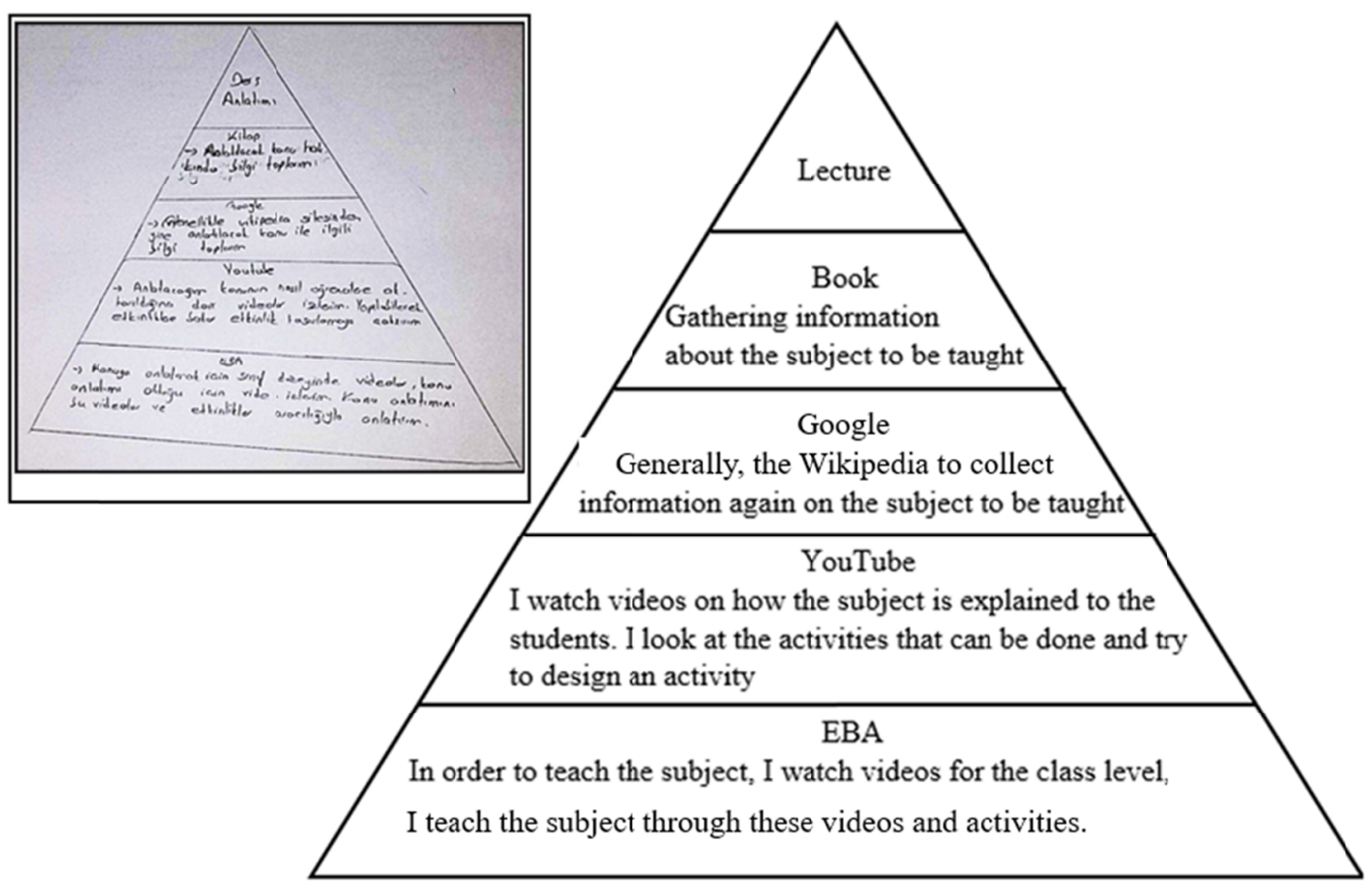

Figure 2. Teacher candidate T5's SRRS

Teacher candidates stated that they use YouTube for knowledge of educational content during clinical interviews. The T17 and T6's statements are given as an example: "I'm looking at Youtube in terms of narration, like what they said before, how they got into the subject and in what order they gave the activities" and "T6: There are videos taken by teachers on Youtube or these videos show how they explained their lessons and how they designed the material on the subject." The importance given by teacher candidates to Youtube videos in their resource systems was interpreted as the weakness of self-confidence in terms of critical thinking dispositions. This weakness of self-confidence was thought to be linked to the lack of teacher candidates' experience, which reinforced their search for truth and open-mindedness aspects of critical thinking.

It was found that the Google search engine was the tool of the Internet most used by teachers in training. Teachers said they found their sources, especially about content knowledge, through the Google search engine. In addition, some teacher candidates said they used Google to search sites like Youtube and Wikipedia. Only five teacher candidates (T3, T4, T5, T10, T25) included EBA, a resource-sharing and information website of the Ministry of Education in Turkey. In digital sources other than the Internet, a teacher candidate (T10) included software such as Cabri, Mapple, and two teacher candidates (T12, T25) included digital textbooks in their source systems. In terms of critical thinking dispositions, searching for the true component can be associated with searching for the correctness of the information found on the Internet. Analyses of the data showed that this disposition varied greatly from one teacher candidate to another. Some teacher candidates expressed blind trust in the information provided by the Internet. The teacher candidate T7's speech was an example of such kind of trust based on unique criteria of popularity "I trust the internet resources ... for example, a video on YouTube, watched several times ... it means that everyone has watched, everyone trusts, the whole world trusts it ... so I trust it, as well." Indeed, the teacher candidate T7 measured the degree of truth of a YouTube resource by its popularity; this finding was interpreted as some teacher candidates chose their resources using criteria against critical thinking. By contrast, some teacher candidates showed selection criteria that conform to critical thinking by systematically analyzing the quality of the resources found on the Internet. The teacher candidate T9 declared, for example, "I never take a resource such that I am still obliged to adapt it ... to modify it so that it conforms to me" (...) "when I work, I always have at least seven tabs open, and I switch from one to another to choose the information that seems most consistent and convenient to me." So, this action of filtering, adapting, comparing the information found on the Internet was interpreted to conform to the disposition "search for the truth" of critical thinking. 
It was noticed that the second resource that drew attention in the teacher candidates' schematic representation of resource systems was substantial and written resources. Analyses of the data showed that 25 out of the 26 teacher candidates used non-numerical written resources, namely the books they studied during their undergraduate training, textbooks, competition preparation books, theses, course notes and official programs. This almost unanimous use of concrete written resources was justified because teacher candidates expressed their confidence in this resource type. For example, the teacher candidate T4 justified this as: "I trust the published books more because there is a commission that validates ... they correct ... they cannot publish everything as a book ... whereas, on the internet, there is everything and whatever matters". The trust of the teacher candidates in the written materials was justified by specific facts involving the scientific community and the publication process. This justification was interpreted as involving a sort of critical thinking.

On the other hand, a teacher candidate expressed his trust in some written materials by a justification that was interpreted as contradictory to critical thinking. The justification of this teacher candidate's trust in a written is as follows: "Of course I trust the book of Teacher M. A, all the words inside is true for me ... For example, I say, about mathematics, $2+2=4$ Teacher $M$. says $2+2=5$... I doubt myself ... because I trusted in this teacher but ... but I do not do the same if I see the information on the Internet ... As I know this teacher, I do what he says, I, of course, trust him." This justification, not involving critical thinking, was interpreted as the obedience to the authority by accepting the information given by it without considering any disposition of critical thinking. The teacher candidate T7 showed very low self-confidence in his/her schematic representation and his/her interview. The teacher candidate T7 was analyzed as open-minded but with weak self-confidence. All the resources cited in his/her schematic representation were external, and his/her schematic representation was composed of few resources (Figure 3). The teacher candidate T7's schematic representation was a tree-type representation, and he/she did not show an analytical disposition in his/her schematic representation. In the interviews, the statements that show weak critical thinking to solve the problem were noticed. An example of such a statement is "... I prefer the resources that someone has prepared. No need to search and waste time... already ready".
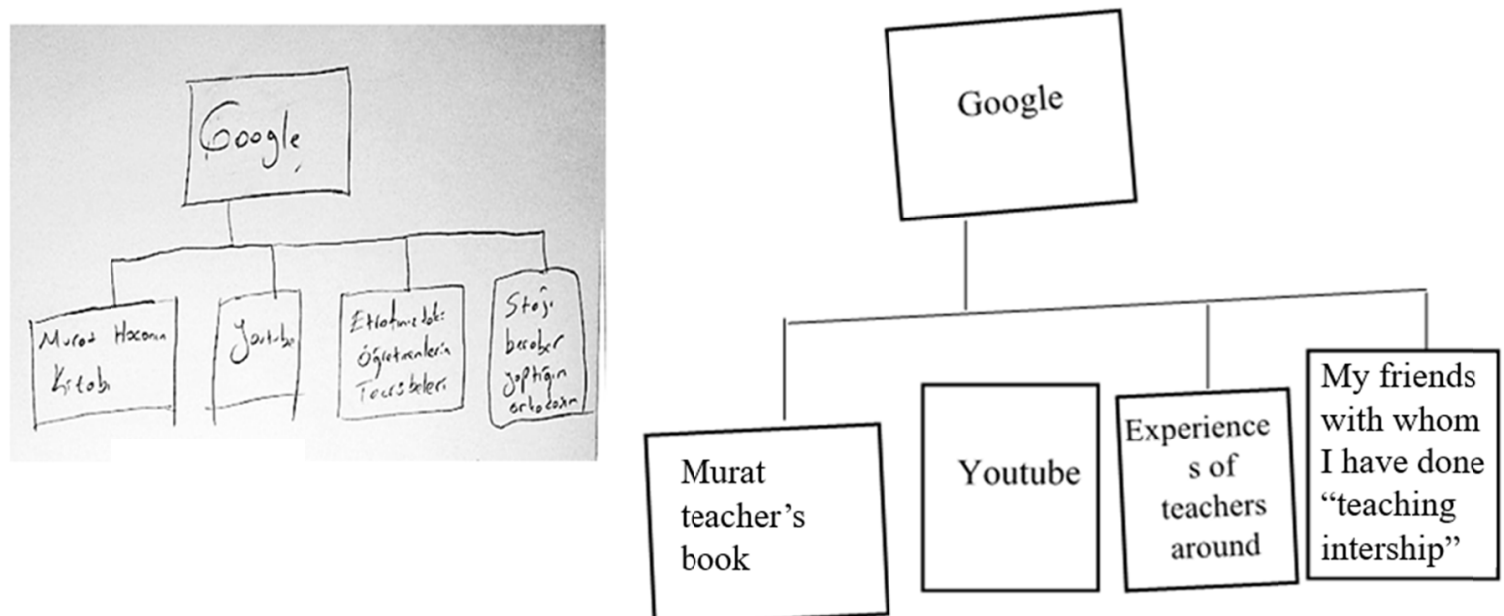

Figure 3. Teacher candidate T7's SRRS

When the schematic representations of teachers' resource systems were evaluated for their types, the teacher candidates' representations were regrouped into four categories: circular, pyramid, tree, and flow chart schematic representations. These different types of schematic representation seemed to be related to different critical thinking dispositions.

Analyses of schematic representations of resource systems parallel to the interviews showed that some teacher candidates constructed a circular schematic representation without specifying a particular order or a particular beginning element. These schematic representations were analyzed as a systematic weakness. The teacher candidate T3 was one of the three teacher candidates (T3, T9, T20) who included himself/herself and his/her experiences in the schematic representation. This teacher candidate was analyzed as a high self-confidence disposition of critical thinking. The schematic representations of resource systems of the teacher candidate T3 
are given in Figure 4.

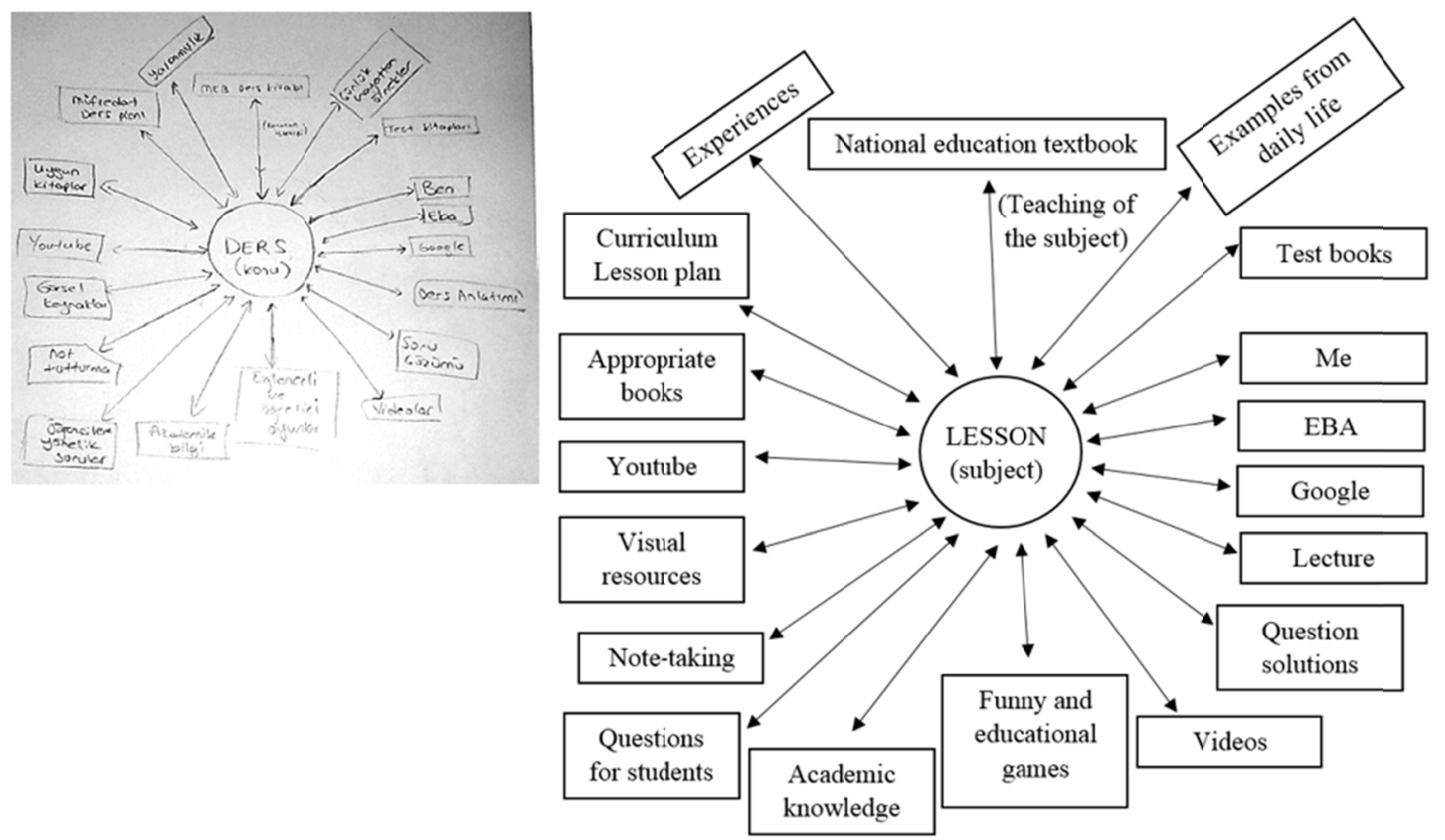

Figure 4. Teacher candidate T3's SRRS

During the interviews, the teacher candidate $\mathrm{T} 3$ states "...of course my opinion is a priority. I may look what others say, but if they are contradictory to my opinion, I don't take them into account". This statement of T3 was analyzed as a weakness in open-mindedness in critical thinking. Another point noticed in teacher candidate T3's interview was that data analyses were the weakness of truth-seeking of critical thinking. An example of a statement illustrating these weaknesses is as follows: "T3: I don't search in all of the resources that I cited in my diagram at the same time... Sometimes it is only textbooks, sometimes it is Youtube... but in the globality, I can search in those resources. Indeed, I wouldn't say I like to do many pieces of research while looking for resources. There is no need to investigate as long as it is sufficient."

Analyses also showed that some schematic representations were simple on the paper, but the interview data indicated that the resources systems of the schematic representations were strong. An example of this is the teacher candidate T8's schematic representation of the resource system (Figure 5).
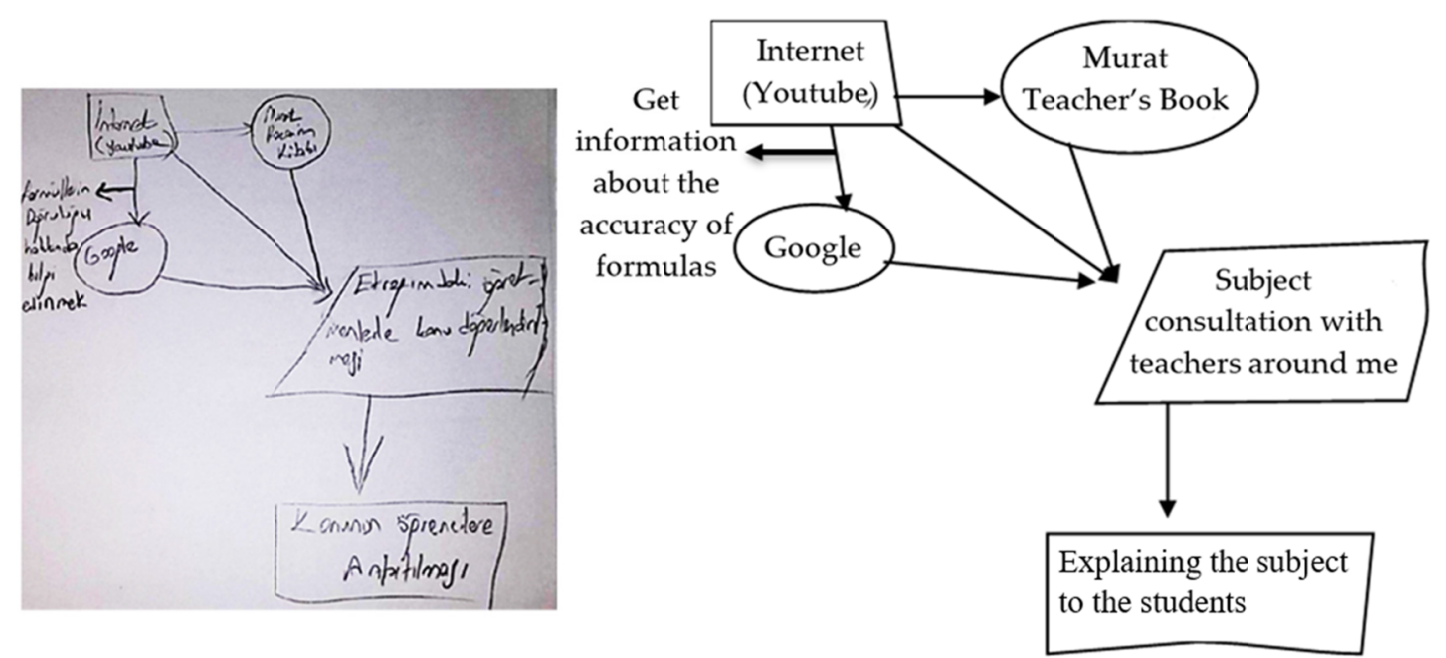
Figure 5. Teacher candidate T8's SRRS

The interview data of the teacher candidate $\mathrm{T} 8$ indicated that he/she did not reflect the importance of searching for accurate resources in his/her schematic representation. Indeed, during the interviews, he/she explained: “... correct information is important, so I have to find the correct information on a subject and also how to teach a subject... to be able to judge the accuracy of the information I have to do a lot of searches. The more documents, more resources, more information I can get about teaching a subject, the better I can teach it...". Analyses of the interview data of T8 related to his/her schematic representation showed that he/she reflected a strong truth-seeking and open-minded disposition. On the contrary, the teacher candidate T8 did not reflect self-confidence in his/her schematic representation, and the interviews supported this finding. In the examples he/she gave during the interview, he/she observed his/her great importance to people's opinions that he/she accepted as authority. The expressions below illustrate the weak self-confidence disposition of critical thinking and obedience to authority. "For example, we had homework on how to teach a topic in geometry recently. It was group homework, and there were three friends in my group. In an empty classroom, we were thinking about how we could teach the subject. When I was walking around the classroom, the teacher Murat saw me from outside. He wondered and asked me what I was doing. I asked him how I can teach this topic? He explained to me that how I could teach it. I don't doubt his reliability on ... He is my formator; he knows a lot... Everybody listens to him."

Another type of schematic representation of resource system retrieved from the analyses was tree-type schematic representations. The teacher candidates who drew a tree-type schematic representation were analytical and systematics in the representations and interviews data analyses. The teacher candidate T13's schematic representation is given in Figure 6 as an example to illustrate the tree-type schematic representation resource system.
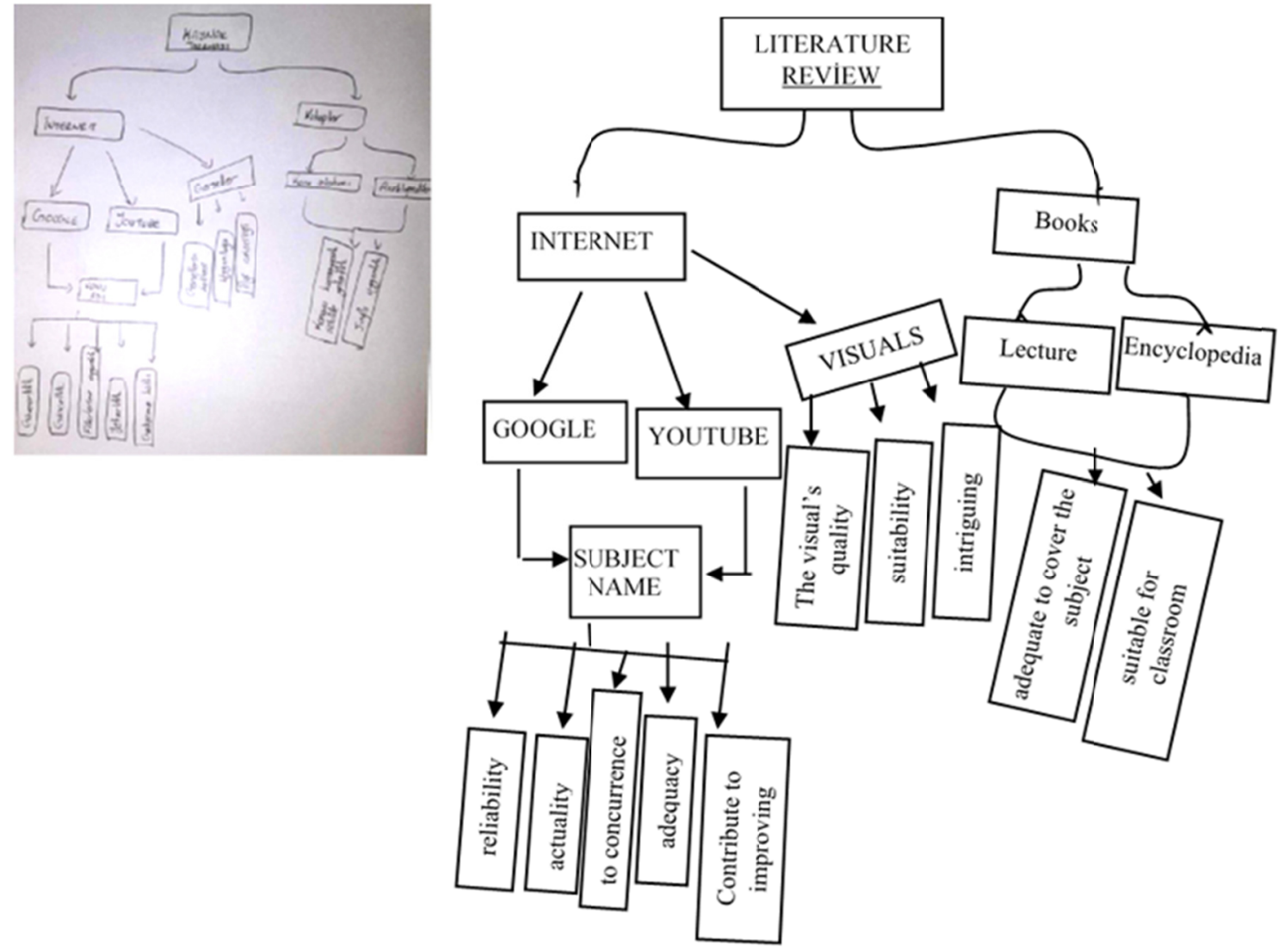

Figure 6. Teacher candidate T13's SRRS

The teacher candidate T13's schematic representation and interview data show a systematic disposition; his/her statement "I first look the internet then the books in the order, because the Internet is easier to access." is an exemple of expression analysed as systematic disposition of critical thinking. The analyse of his interviews 
related to his schematic representations revealed a high self-confidence and analytical disposition. The statement “... for example, if I have already knowledge on a subject... and if I constructed this knowledge with doing researches on a scientific manner, or if I had it with my life experiences... then I know that my thoughts are generally trued... then I know that my thoughts are generally trues..." can be given as an example of expression analyzed as self-confidence disposition. For the open-minded and analytical dispositions, the statement "I mean, if I find my thoughts true if I have proof, I accept my thoughts. But if another person has a different opinion, I listen to him/her and ask to prove his/her thoughts. If he/she reaches a proof and I convince myself, then I will accept his/her opinion." can be an example.

Concerning the findings obtained by the analyses of the schematic presentation of mathematics teacher candidates, the five themes "truth-seeking", "open-minded", "analytic", "systematic" and "self-confidence" were found out as critical thinking dispositions. These themes and the codes associated with these themes are summarized in Table 1. 
Table 1. Codes and themes derived from the analysis of the SRRS

\begin{tabular}{ll}
\hline Themes & Codes \\
\hline truth-seeking & Digital resources \\
& Concrete/written resources \\
& Verbal/collective resources \\
open-minded & Colleagues as a resource \\
& Academics as a resource \\
& Students as a resource \\
analytical & Specify the direction in the schematic representation \\
& Explanation in the schematic representation \\
& Linking in the schematic representation \\
systematic & Hierarchical organization in the schematic representation \\
& Conclusive organization in the schematic representation \\
& Holistic organization in the schematic representation \\
self-confidence & Applying his/her knowledge as a resource \\
& Applying his/her training as a resource \\
& Applying his/her resources to reach the conclusion \\
\hline
\end{tabular}

When each teacher candidate's schematic representations were analyzed for the five themes of critical thinking dispositions, it was understood that some dispositions of truth-seeking were highly present. Still, some dispositions as self-confidence were weak. These findings were revealed to be coherent with the findings of clinical interview analyses related to the schematic representations.

Findings of each mathematics teacher candidates' schematic representation of resource systems in terms of critical thinking dispositions are presented in Table 2 . 
Table 2. Frequencies of SRRS in terms of critical thinking

\begin{tabular}{|c|c|c|c|c|c|c|c|c|c|c|c|c|c|c|c|}
\hline \multirow[b]{2}{*}{ Students } & \multicolumn{3}{|c|}{ Truth-seeking } & \multicolumn{3}{|c|}{ Open-minded } & \multicolumn{3}{|c|}{ Analytical } & \multicolumn{3}{|c|}{ Systematic } & \multicolumn{3}{|c|}{ Self-confidence } \\
\hline & 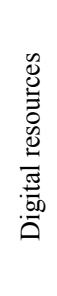 & 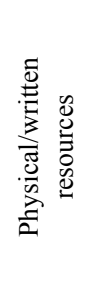 & 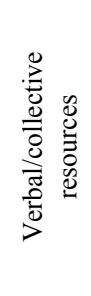 & $\begin{array}{l}\stackrel{\Xi}{0} \\
\tilde{\Xi} \\
\stackrel{\Xi}{0}\end{array}$ & 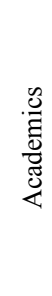 & 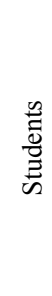 & 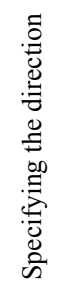 & 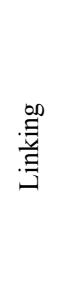 & 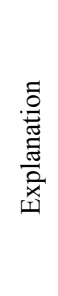 & 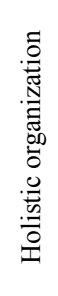 & 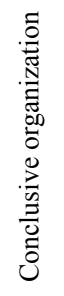 & 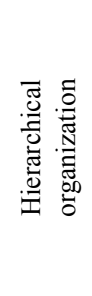 & 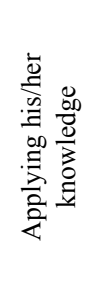 & 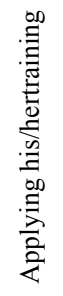 & 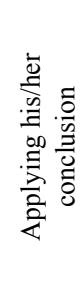 \\
\hline $\mathrm{T} 1$ & $\mathrm{x}$ & $\mathrm{x}$ & $\mathrm{x}$ & $\mathrm{x}$ & & & $\mathrm{x}$ & & & & & $\mathrm{x}$ & $\mathrm{x}$ & & \\
\hline $\mathrm{T} 2$ & $\mathrm{x}$ & $\mathrm{x}$ & $\mathrm{x}$ & $\mathrm{x}$ & & $\mathrm{x}$ & $\mathrm{x}$ & & $\mathrm{x}$ & & & $\mathrm{x}$ & & & \\
\hline $\mathrm{T} 3$ & $\mathrm{x}$ & $\mathrm{x}$ & & & & & $\mathrm{x}$ & & & & & $\mathrm{x}$ & $\mathrm{x}$ & $\mathrm{x}$ & \\
\hline $\mathrm{T} 4$ & $\mathrm{x}$ & $\mathrm{x}$ & $\mathrm{x}$ & $\mathrm{x}$ & & $\mathrm{x}$ & & & $\mathrm{x}$ & & & $\mathrm{x}$ & & $\mathrm{x}$ & \\
\hline T5 & $\mathrm{x}$ & $\mathrm{x}$ & & & & & & & $\mathrm{x}$ & & & $\mathrm{x}$ & & & $\mathrm{x}$ \\
\hline T6 & $\mathrm{x}$ & $\mathrm{x}$ & $\mathrm{x}$ & & & $\mathrm{x}$ & $\mathrm{x}$ & $\mathrm{x}$ & $\mathrm{x}$ & $\mathrm{x}$ & $\mathrm{x}$ & & $\mathrm{x}$ & & $\mathrm{x}$ \\
\hline $\mathrm{T} 7$ & $\mathrm{x}$ & $\mathrm{x}$ & $\mathrm{x}$ & $\mathrm{x}$ & & & & & & & & $\mathrm{x}$ & & & \\
\hline $\mathrm{T} 8$ & $\mathrm{x}$ & $\mathrm{x}$ & $\mathrm{x}$ & $\mathrm{x}$ & & & $\mathrm{x}$ & $\mathrm{x}$ & $\mathrm{x}$ & $\mathrm{x}$ & $\mathrm{x}$ & & & & \\
\hline T9 & $\mathrm{x}$ & $\mathrm{x}$ & $\mathrm{x}$ & $\mathrm{x}$ & $\mathrm{x}$ & & $\mathrm{x}$ & $\mathrm{x}$ & $\mathrm{x}$ & $\mathrm{x}$ & $\mathrm{x}$ & & $\mathrm{x}$ & $\mathrm{x}$ & $\mathrm{x}$ \\
\hline $\mathrm{T} 10$ & $\mathrm{x}$ & $\mathrm{x}$ & & & & & $\mathrm{x}$ & & & $\mathrm{x}$ & & & & & \\
\hline T11 & $\mathrm{x}$ & $\mathrm{x}$ & $\mathrm{x}$ & $\mathrm{x}$ & & $\mathrm{x}$ & & & & & & $\mathrm{x}$ & & & \\
\hline $\mathrm{T} 12$ & $\mathrm{x}$ & $\mathrm{x}$ & & & & & $\mathrm{x}$ & & & & & $\mathrm{x}$ & & & \\
\hline $\mathrm{T} 13$ & $\mathrm{x}$ & $\mathrm{x}$ & & & & & $\mathrm{x}$ & $\mathrm{x}$ & $\mathrm{x}$ & & $\mathrm{x}$ & $\mathrm{x}$ & & & $\mathrm{x}$ \\
\hline $\mathrm{T} 14$ & $\mathrm{x}$ & $\mathrm{x}$ & $\mathrm{x}$ & $\mathrm{x}$ & & $\mathrm{x}$ & $\mathrm{x}$ & & & & & $\mathrm{x}$ & $\mathrm{x}$ & & \\
\hline T15 & $\mathrm{x}$ & $\mathrm{x}$ & & & & & & & & & & $\mathrm{x}$ & & & \\
\hline T16 & $\mathrm{x}$ & $\mathrm{x}$ & $\mathrm{x}$ & $\mathrm{x}$ & & & $\mathrm{x}$ & $\mathrm{x}$ & & & $\mathrm{x}$ & $\mathrm{x}$ & & & \\
\hline T17 & $\mathrm{x}$ & & & & & & & & $\mathrm{x}$ & & & $\mathrm{x}$ & $\mathrm{x}$ & & \\
\hline T18 & $\mathrm{x}$ & $\mathrm{x}$ & $\mathrm{x}$ & & & $\mathrm{x}$ & $\mathrm{x}$ & & $\mathrm{x}$ & & & $\mathrm{x}$ & $\mathrm{x}$ & & \\
\hline T19 & $\mathrm{x}$ & $\mathrm{x}$ & $\mathrm{x}$ & $\mathrm{x}$ & & $\mathrm{x}$ & $\mathrm{x}$ & & $\mathrm{x}$ & & & $\mathrm{x}$ & & & \\
\hline $\mathrm{T} 20$ & $\mathrm{x}$ & $\mathrm{x}$ & $\mathrm{x}$ & $\mathrm{x}$ & & $\mathrm{x}$ & $\mathrm{x}$ & $\mathrm{x}$ & $\mathrm{x}$ & $\mathrm{x}$ & $\mathrm{x}$ & & $\mathrm{x}$ & $\mathrm{x}$ & $\mathrm{x}$ \\
\hline $\mathrm{T} 21$ & $\mathrm{x}$ & $\mathrm{x}$ & & & & & $\mathrm{x}$ & $\mathrm{x}$ & $\mathrm{x}$ & & $\mathrm{x}$ & $\mathrm{x}$ & & & $\mathrm{x}$ \\
\hline $\mathrm{T} 22$ & $\mathrm{x}$ & $\mathrm{x}$ & & & & & $\mathrm{x}$ & & $\mathrm{x}$ & & $\mathrm{x}$ & $\mathrm{x}$ & & & \\
\hline $\mathrm{T} 23$ & $\mathrm{x}$ & $\mathrm{x}$ & $\mathrm{x}$ & $x$ & $\mathrm{x}$ & & $\mathrm{x}$ & & $x$ & & & $\mathrm{x}$ & $\mathrm{x}$ & & \\
\hline $\mathrm{T} 24$ & $\mathrm{x}$ & $\mathrm{x}$ & & & & $\mathrm{x}$ & & & $\mathrm{x}$ & & & $\mathrm{x}$ & & & \\
\hline $\mathrm{T} 25$ & $\mathrm{x}$ & $\mathrm{x}$ & $\mathrm{x}$ & $\mathrm{x}$ & $\mathrm{x}$ & & $\mathrm{x}$ & $\mathrm{x}$ & $\mathrm{x}$ & & $\mathrm{x}$ & $\mathrm{x}$ & & & \\
\hline T26 & $\mathrm{x}$ & $\mathrm{x}$ & & & & & $\mathrm{x}$ & & & $\mathrm{x}$ & $\mathrm{x}$ & & & & \\
\hline Total & 26 & 25 & 15 & 13 & 3 & 9 & 19 & 8 & 16 & 6 & 10 & 20 & 9 & 4 & 6 \\
\hline
\end{tabular}

When the schematic representations of mathematics teacher candidates were evaluated in the truth-seeking disposition, it was quite high. By open-minded disposition, it was understood that the teacher candidates chose that took less consideration of the other's opinions and thoughts when making decisions. In terms of analytical disposition, mathematics teacher candidates presented a few links in the document-making processes. In addition, it was observed that teacher candidates' critical thinking dispositions in terms of self-confidence were low. Remarkably, they tended to use a knowledge-based decision-making strategy that followed a certain procedure. The most remarkable result of the analysis of the schematic representations of the documentation systems was that teacher candidates reflected their confidence in their reasoning processes less. Another result was that curiosity, cognitive maturity and critical thinking disposition dimensions could not be determined in their schematic representation.

\section{Conclusion and Discussion}

Resource systems have been presented in different representations by teachers. Typical curricular resources included text resources (e.g., textbooks, curricular guidelines, student worksheets) or digital curriculum resources (e.g., digital interactive textbooks). This study explains the teacher candidates' resource preferences and their critical thinking dispositions using their schematic representations of resource systems. According to the study results, it is noted that mathematics teacher candidates are more oriented towards digital resources, 
especially internet resources. Similarly, Gueudet, Soury-Lavergne and Trouche (2008) have concluded that digital resources are important in teachers' professional lives. When it is considered that today is a technology-based era, it is thought that digital and electronic resources that affect all of our living conditions have also affected teachers' document construction process.

Considering teacher candidates' SRRS by critical thinking, digital resource preferences can be associated with the truth-seeking disposition of critical thinking. In the interviews, teachers supported this disposition by expressing that they used digital resources to search for more truth. Trouche, Gitirana, Miyakawa, Peppin and Wang (2019) have noticed that teachers work forms an inquiry, asking questions, looking for answers in different resources for developing their answers. Besides, the fact that mathematics teacher candidates are open to working with different people in their lesson preparation is compatible with the orientations of the documentational approach's collective work and open-mindedness in critical disposition. Kurfiss (1988, p. 20) defines critical thinking as research that seeks to construct a hypothesis or conclusion that presents a phenomenon, problem, or problem. It includes all the available information and can convincingly confirm it. It necessitates a complete metamorphosis of thinking and acting, particularly in education: new balances between static and dynamic resources, between using and designing teaching resources, between individual and collective work (Pepin, Gueudet, \& Trouche, 2017). As there is now nearly unlimited access to resources on the web, teachers often lose themselves to choose the most didactically and qualitatively appropriate resources for their mathematics teaching (Trouche, Gueudet, \& Pepin, 2018). The digitalization of information and communication and the development of the Internet had strong consequences: ease of quick access to many resources and communication with many people.

In this study, the representations and analytical and systematic dispositions in critical disposition have been interpreted to be related. Critical thinking is developing knowledge-based skills or practicing exercises based on experiences and the continued use and development of analytical skills (Paul, 2005). Therefore, in this study, it has been found that candidates preferred direction and explanation as analytical orientation and hierarchical representation as a systematic orientation. In the interviews, they used expressions that supported the relationship between these representations and analytic and systematic dispositions. It is noteworthy that in the schematic representations of the resource systems, teachers show little or no representation of themselves or their elements in the schematic representations. However, in the studies conducted with experienced teachers, it is stated that the participants refer to their SRRS or their elements, and even some teachers place themselves at the center as a primary source in the demonstration (Basturk Sahin, 2015). These two results do not match each other, and it may be because our participants were not experienced teachers. In terms of critical thinking disposition, this disposition has been observed to be weak. This situation is related to the fact that teacher candidates are newer in the profession.

The findings of this study show that in each component of critical thinking dispositions, the teacher candidates have tendencies to obey the authority, which is an obstacle to critical thinking. However, if teacher candidates become aware of the existence of the reasoning errors, then their documentational research methodology can be greatly improved. The usefulness of the schematic representations lies in the fact that it is necessary to analyze whether the teacher candidate makes reasoning errors in the justification of his/her documentational research methodology for each component. A good documentational research does not involve shaping critical thinking dispositions devoid of any error of reasoning, namely obedience to authority. So, when we consider the documentational genesis in the teacher training, it can be hypothesized that, like any cognitive scheme, the schemes related to the documentational system of teacher candidates are a concept to be constructed within the teacher training institution. Training that does not consider the collection and integration of resources can be said to be incomplete.

Consequently, in this study, it has been noticed that both teachers' resource preferences and their critical thinking dispositions can be revealed by using their schematic representation of resource systems. As a result of this study, considering that the preferred resources are essential for effective teaching of lessons by teachers. This study also reveals that teacher candidates give more importance to digital resources. In addition, it has been noted that their resource preferences are related to their critical thinking dispositions. The resources that affect the professional development of teachers who will just start their profession are related to their resource preferences and critical thinking dispositions.

\section{References}

Adihou, A., Gibel, P., \& Blanquart-Henry, S. (2019). Méthodologie pour l'étude didactique d'un entretien formateur/professeur stagiaire en mathématiques dans le cadre d'une visite de classe. Canadian Journal of 
Science, Mathematics and Technology Education, 19(2), 143-167. https://doi.org/10.1007/s42330-019-00047-9

Adler, J. (2000). Conseptualising resources as a theme for teacher education. Journal of Mathematics Teacher Education, 3, 205-224. https://doi.org/10.1023/A:1009903206236

Basturk Sahin, B. N. (2015). The analysis of primary mathematics teachers' lesson document preparing processes. Master Theses, Uludag University. Retrieved from https://acikerisim.uludag.edu.tr/bitstream/11452/2716/1/407254.pdf

Caine, R. N., \& Caine, G. (1991). Making connections: Teaching and the human brain. Alexandria, VA: Association for Supervision and Curriculum Development.

Facione, N. C., Facione, P. A., \& Sanchez, C. A. (1994). Critical thinking disposition as a measure of competent clinical judgment: The development of the California Critical Thinking Disposition Inventory. Journal of Nursing Education, 33(8), 345-350. https://doi.org/10.3928/0148-4834-19941001-05

Gueudet, G., Soury-Lavergne, S., \& Trouche, L. (2008, September 4-6). Soutenir l'intégration des TICE: quels assistants méthodologiques pour le développement de la documentation collective des professeurs? Exemples du SFoDEM et du dispositif Pairform@nce. Proceedings of the Colloque DIDIREM Approches plurielles en didactique des mathématiques, Paris, France. Retrieved from https://hal.archives-ouvertes.fr/hal-00460303/document

Gueudet, G., \& Trouche, L. (2008). Du travail documentaire des enseignants: genèses, collectifs, communautés. Le cas des mathématiques. Education et didactique, 2(3), 7-33. https://doi.org/10.4000/educationdidactique.342

Gueudet, G., \& Trouche, L. (2010). Des ressources aux documents, travail du professeur et genèses documentaires, In G. Gueudet \& L. Trouche (Eds.), Ressources vives. Le travail documentaire des professeurs en mathématiques (pp. 57-74). Presses Universitaires de Rennes et INRP. Retrieved from https://hal.univ-brest.fr/hal-00497305/

Gueudet, G., \& Trouche, L. (2011). Développement de l'Internet dans l'enseignement: vers un essor du collectif? In C. Develotte \& F. Poyet (Eds.), L'éducation à l'heure du numérique, état des lieux, enjeux et perspectives (pp. 145-165). Lyon: INRP-ENSL. Retrieved from https://hal.archives-ouvertes.fr/hal-00591221

Hammoud, R. (2012). Le travail collectif des professeurs en chimie comme levier pour la mise en oeuvre de demarches d'investigation et le developpement des connaissances professionnelles. Contribution au developpement de l'approche documentaire du didactique. Doctorate dissertation, Lyon 1 University. Retrieved from https://tel.archives-ouvertes.fr/tel-00762964/document

Kurfiss, J. G. (1988). Critical Thinking: Theory, Research, Practice and Possibilities. ASHE-ERIC Higher Education Report No.2. Washington, DC: Association for the Study of Higher Education. Retrieved from http://files.eric.ed.gov/fulltext/ED304041.pdf

Patton, M. Q. (2015). Qualitative research and evaluation methods (4th ed.). Thousand Oaks, CA: Sage.

Paul, R. (2005). The state of critical thinking today. New Directions for Community Colleges, 130, 27-38. https://doi.org/10.1002/cc.193

Pepin, B., Geudet, B., Yerushalmy, M., Trouche, L., \& Chazan, D. I. (2016). E-textbooks in/for teaching and learning mathematics: A potentially transformative educational technology. In L. English \& D. Kirshner (Eds.), Handbook of Research in Mathematics Education (3rd ed., pp. 636-661). New York: Taylor\&Francis.

Pepin, B., Gueudet, G., \& Trouche, L. (2013). Re-sourcing teachers' work and interactions: A collective perspective on resources, their use and transformations. ZDM, 45(7), 929-944. https://doi.org/10.1007/s11858-013-0534-2

Pepin, B., Gueudet, G., \& Trouche, L. (2017). Refining teacher design capacity: Mathematics teachers' interactions with digital curriculum resources, ZDM, 49(5), 799-812. https://doi.org/10.1007/s11858-017-0870-8

Rocha, K. D. M. (2018). Uses of online resources and documentational trajectories: The case of Sesamath. In L. Fan, L. Trouche, S. Rezat, C. Qui \& J. Visnovska (Eds.), Research on Mathematics Textbooks and Teachers' Resources: Advances and Issues (pp. 235-258). Springer. https://doi.org/10.1007/978-3-319-73253-4_11

Trouche, L., Gitirana, V., Miyakawa, T., Pepin, B., \& Wang, C. (2019). Studying mathematics teachers' 
interactions with curriculum materials through different lenses: Towards a deeper understanding of the processes at strake. International Journal of Eduational Research, 93, 53-67. https://doi.org/10.1016/j.ijer.2018.09.002

Trouche, L., Gueudet, G., \& Pepin, B. (2018). Documentational approach to didactics. In S. Lerman (Ed.), Encyclopedia of Mathematics Education. Springer. https://doi.org/10.1007/978-3-319-77487-9_100011-1

Yin, R. K. (2009). Case Study Research Design and Methods (4th ed.). Sage.

\section{Copyrights}

Copyright for this article is retained by the author, with first publication rights granted to the journal.

This is an open-access article distributed under the terms and conditions of the Creative Commons Attribution license (http://creativecommons.org/licenses/by/4.0/). 